\title{
ONLINE COPING WITH THE FIRST WAVE: COVID HUMOR AND RUMOR ON DUTCH SOCIAL MEDIA (MARCH - JULY 2020)
}

\author{
Theo Meder \\ Professor \\ Meertens Instituut, Amsterdam, Netherlands \\ theo.meder@meertens.knaw.nl \\ University of Groningen, Groningen, Netherlands \\ t.meder@rug.nl
}

\begin{abstract}
In the course of March 2020, the Netherlands, Flanders, and a large part of Europe were affected by the first wave of the COVID-19 virus. For four months, the population was in lockdown, and many issues had to be handled online. Social media became important to keep in touch with and to air opinions. Two folktale genres, namely the joke and the modern legend, were used to express frustrations, malicious pleasures, fears, and feelings of distrust. During the first wave, Theo Meder and Mathijs Kroon did some intensive collecting of jokes, memes, fake news, and conspiracy theories. It was expected by folktale researchers like Giselinde Kuipers and Theo Meder that, just like in former crises, jokes would contain plenty of morbid disaster humor, but that did not happen. Contemporary legends, on the other hand, were polarizing and toxic, and mistrust was mainly directed against the elite of politicians, scientists, doctors, and journalists. The corona crisis was seen as some kind of hoax in many ways, while most of the "sheeple" refused to wake up. The analysis of folktales during the pandemic provides an insight into the feelings and emotions in society.
\end{abstract}

Keywords: conspiracy theories, corona, COVID-19, fake news, first wave, humor, jokes, legends, memes, pandemic, rumor, social media, virus

With the lockdown in mid-March 2020, many people ended up at home and interest in social media increased, both in the passive and active sense. Up to and including July, for the Dutch Folktale Database ${ }^{1}$ of the Meertens Institute, Mathijs Kroon and I daily collected modern stories that had something to do with the COVID-19 crisis: mainly memes, fake news, and conspiracy theories that represent the folktale subgenres of the joke and the contemporary legend.

It is certainly not the case that this pandemic is unique in generating jokes, rumors, and conspiracy theories: in the (recent) past, for example, the polio, 
AIDS, and SARS viruses also struck worldwide, whereby "members of the public engage[d] in rumors about who has the disease, places and people to avoid, mandatory quarantines, and government health conspiracies" (Goldstein 2004: XIV). It is just that, due to social media, the number of postings has been very large this time.

I mainly collected contributions in the Dutch and Flemish languages, so that it was certain that the message was addressed to a Dutch-speaking community in the Low Countries, although some English, German, and French language variants were sometimes included, because humor and rumors are in general not bound by borders. ${ }^{2}$ Most of the material has been collected on Facebook, ${ }^{3}$ and to a lesser extent on Twitter, YouTube, and internet forums. More than 770 representative stories and memes have been put together in a digital exhibition. ${ }^{4}$ In four months, the entire collection quickly amounted to about 3,000 memes, jokes, and rumors. It is possible that I still missed a few things.

The aim of this article is to exemplify and analyze which emotions and topics are recurrently reflected in the observed material and in what ways various phases of the pandemic and various genres bring in new tonalities.

\section{DISASTER HUMOR AND MINOR SUFFERING}

The corona pandemic can rightly be called a worldwide disaster, and one would therefore expect harsh disaster humor within days or weeks. After all, previous disasters produced such jokes after only a few days: the Dutroux pedophilia affair, the attacks of September 11, the tsunami and nuclear disaster in Japan, etc. (Kuipers 2002, 2005). However, during the corona crisis, morbid jokes emerged neither in the Netherlands and Flanders, nor worldwide (Kuipers 2020). Apparently, the threat was now too serious, too personal, and came too close. The theme of illness and death may be fit for dark humor when people far away are concerned, but apparently is a taboo when people themselves, their family and friends can also be victims. So (maybe partly as a distraction) the focus was mainly on less sensitive subjects. A few fairly innocent jokes were found about death, such as how to assemble a coffin yourself with the IKEA Kövid package.

Another joke played around Easter:

Special message from Jesus: Given the situation this year, I will not be coming down at Easter. You just come up. ${ }^{5}$

These were the darkest jokes about illness and death, and these are nothing compared to the usual morbid disaster humor. 
Figure 1. How to build a coffin with the IKEA Kövid package. Source: http: / / www.verhalenbank.nl/items / show/129105, last accessed on 8 February 2021.

The vast majority of jokes and memes were about relatively

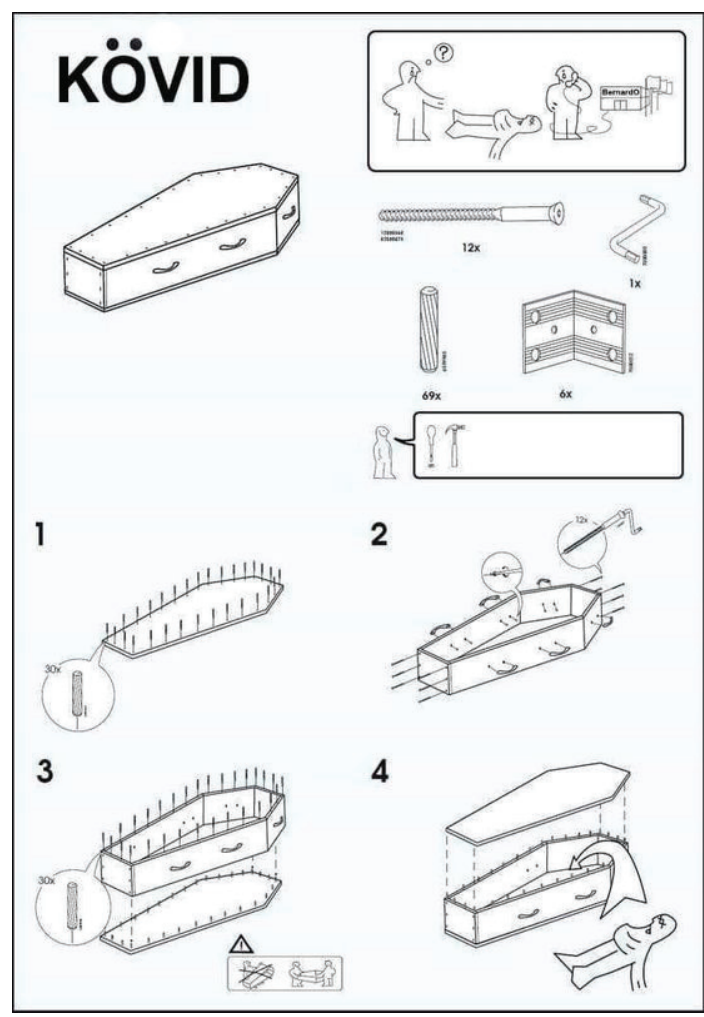
minor suffering: keeping distance, face masks, quarantine, the weather, boredom, working from home, home schooling of children, the bear hunt (people put teddy bears behind the windows for children to spot), relationship problems, alcohol (and closed bars), no hairdresser, no festivals, no sports, and the summer holiday that threatened to be cancelled. Unprecedented creativity was shown in making jokes about these subjects.

For many people with practical professions, who had to be in lockdown but were unable to work from home, boredom quickly set in. ${ }^{6}$ The jokes include a man who has completely disassembled his washing machine, ${ }^{7}$ but is still unable to find that missing sock. Another dismantles his car ${ }^{8}$ and is satisfied that it consists of 35,067 parts. Someone finally has the time to neatly line up all the chocolate sprinkles on his sandwich. ${ }^{9}$ Someone starts counting the rice grains in a kilo pack from two different supermarkets and ends up with an unequal number. ${ }^{10} \mathrm{~A}$ lifeguard has placed his chair in the bathroom and watches over his wife in the bath. ${ }^{11} \mathrm{~A}$ traffic cop flashes traffic offenders on his television, ${ }^{12}$ and a fisherman casts his fishing rods into his own aquarium. ${ }^{13}$ The theme of boredom also includes jokes about pregnancy and the expected baby boom in the winter. ${ }^{14}$ 


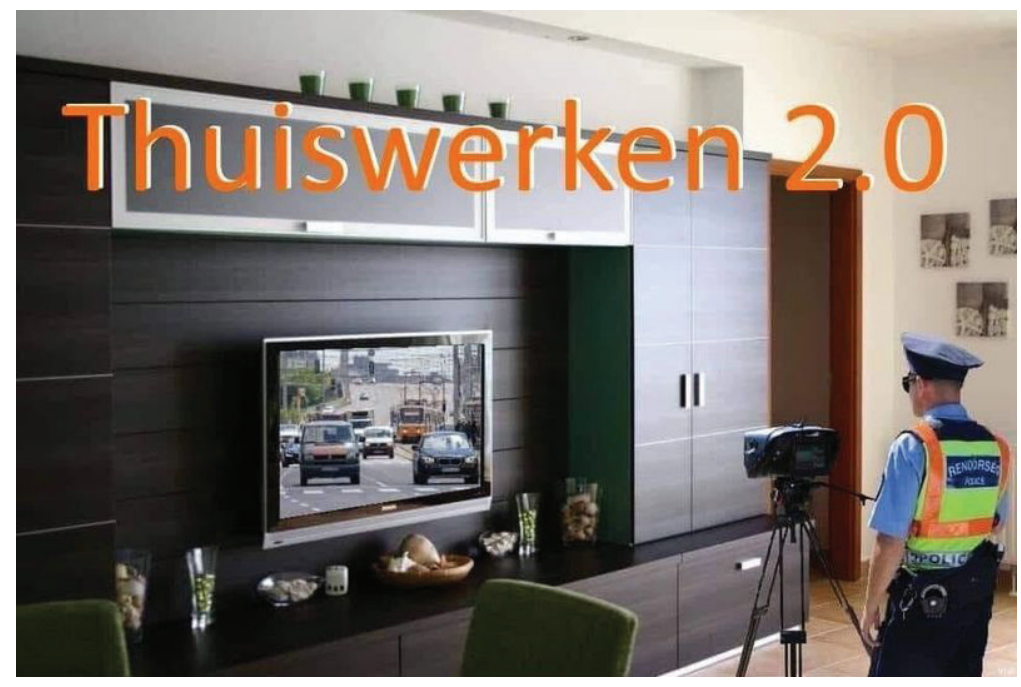

Figure 2. Working from home 2.0. Source: http: / / www.verhalenbank.nl/items / show / 129028, last accessed on 25 February 2021.

\section{Als de kapper tien weken gesloten is}

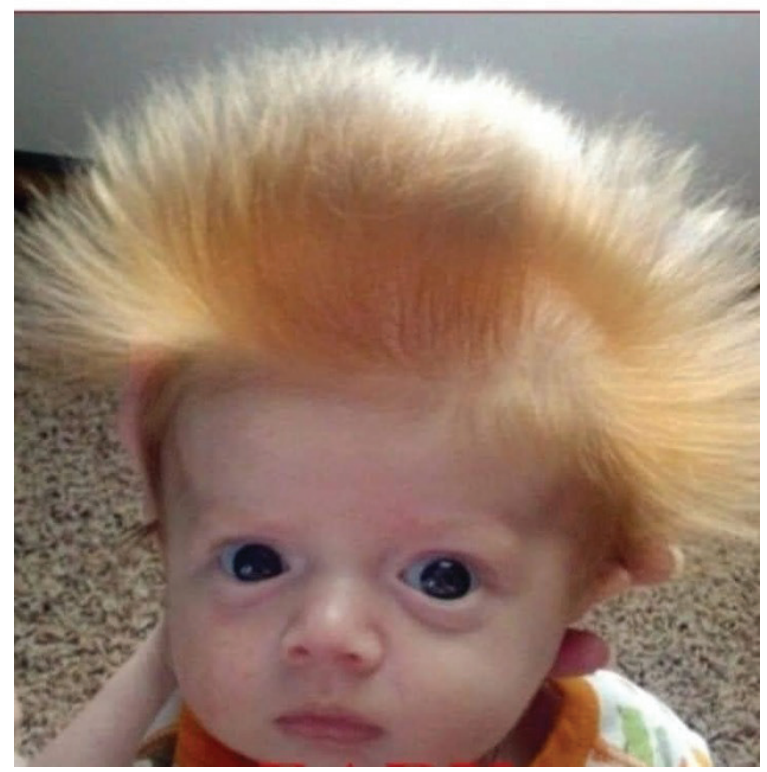

Figure 3. When the hairdresser is closed for ten weeks. Source: http:/ / www.verhalenbank.nl/items/show/128969, last accessed on 25 February 2021. 
The small inconveniences also include the fact that one cannot go to the hairdresser. ${ }^{15}$ Many memes were circulated of overgrown and fierce corona haircuts. People tried to trim their hair a bit at home, but sometimes an ear was lost. ${ }^{16}$ And many hairstyles looked awful after a failed haircut. ${ }^{17}$ In several memes even prostitutes were visited with the question whether they could also (illegally) give a haircut. ${ }^{18}$

A meme that is depicted in several variations is a photograph of a mum or dad working behind the laptop, while the restless children are gagged on the floor. ${ }^{19}$ After all, the parents had to work from home, while the schools were closed. The fact that the parents now had to do homeschooling ${ }^{20}$ turned out to be a problem for some. While working from home, according to several memes and jokes, the children could be a distracting nuisance. ${ }^{21}$ Photographs of a handwritten paper taped to a door, ${ }^{22}$ intended for the children when mum had a meeting via Skype or Zoom, went viral. It concerns a ban on entry, as well as answers to the most frequently asked questions:

Mum is in a meeting!

12:45-15:15

[road sign for no entry]

! Do not come in!

Maybe the answer is

here:

Upstairs

In the laundry basket

I don't know yet what we're eating

No!

In your room

I do not know

Eat an apple

Figure 4. Tied-up children. Source: http: / / www.verhalenbank.nl / items / show / 128881, last accessed on 25 February 2021.

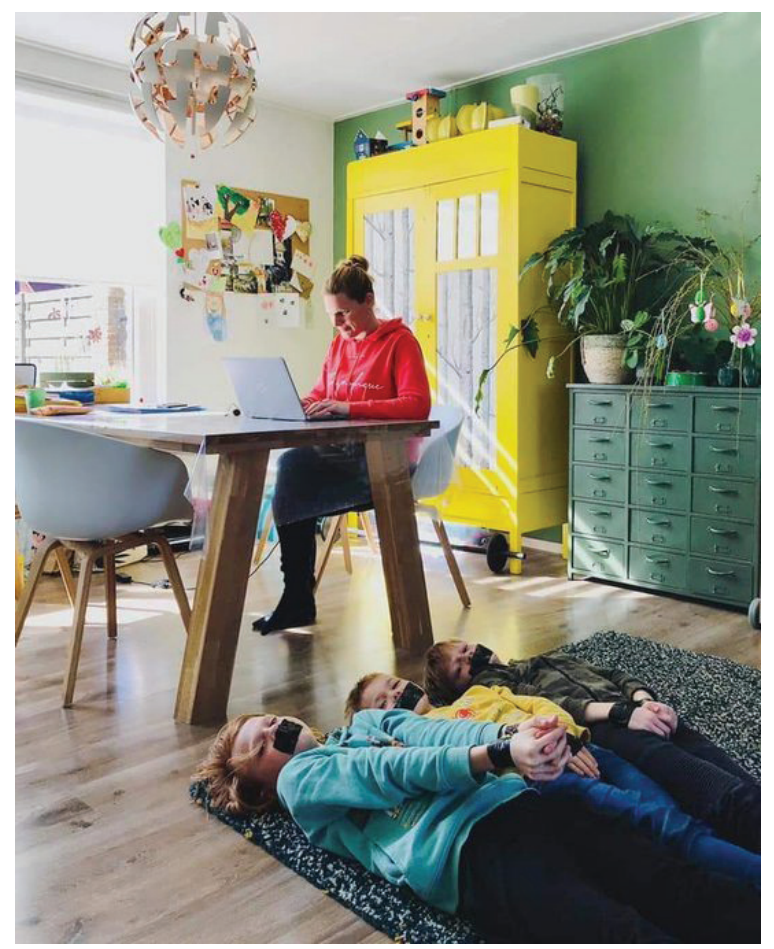




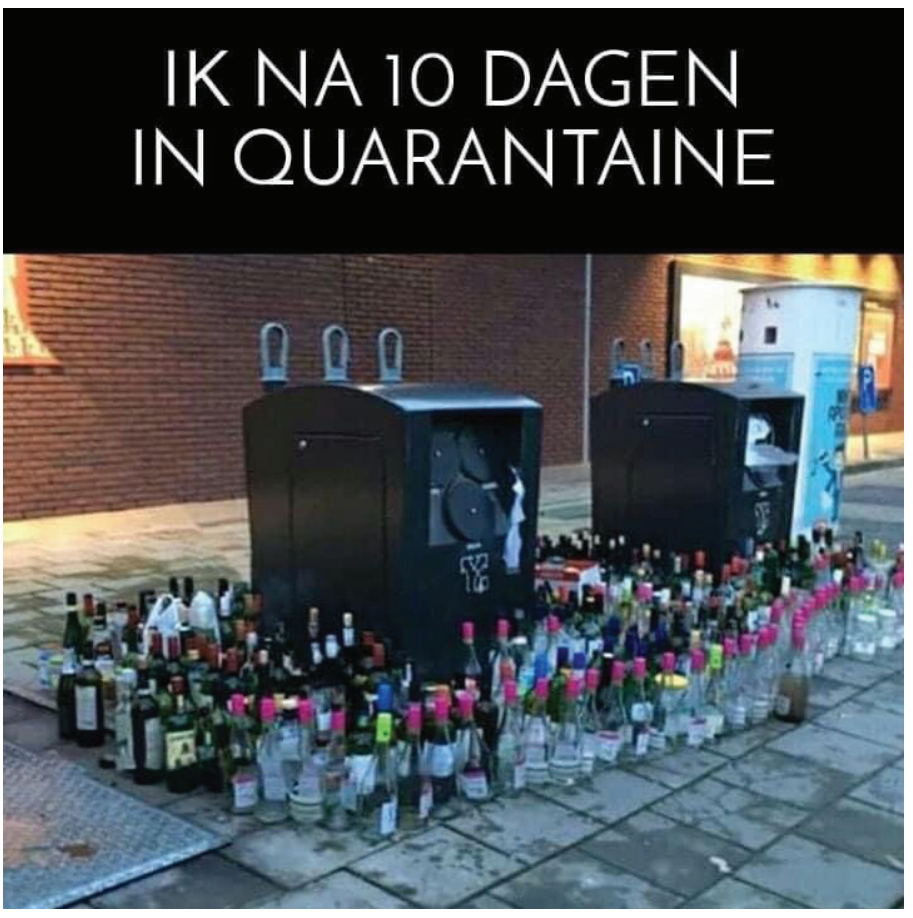

Figure 5. Me after 10 days in quarantine. Source: http://www. verhalenbank.nl/items/show/129336, last accessed on 25 February 2021.

A strikingly recurring theme is the desire for alcohol and pub visits. ${ }^{23}$ While in 2019 people were called losers when sitting on the couch, drinking beer all day, in 2020 such people are heroes ${ }^{24}$ saving lives. Jokes are made about the increased alcohol consumption during quarantine through photographs of a house full of empty beer cans, ${ }^{25}$ or a full bottle bank ${ }^{26}$ with countless empty bottles next to it. It is regularly confirmed that visiting the pub ${ }^{27}$ is sorely missed, because of the alcohol, but certainly also because of the fun of companionship. And of course, a number of jokes have been made about Corona beer. One of the first practical jokes was invented at the beginning of March in a Brussels branch of the Delhaize supermarket chain: when purchasing two bottles of Corona, a bottle of Mort Subite (acute death) was added for free. ${ }^{28}$ The photograph of the advertising offer went viral in no time but was labeled as tasteless humor by the head office. Although the action was quickly halted, memes with Corona and Mort Subite continued to be repeated. Another meme that was circulated internationally in several variations concerns bottles of Heineken beer wearing face masks, to protect themselves against a bottle of Corona beer. ${ }^{29}$ 
There was no lack of creativity or sense of humor, but as said: the jokes and memes during the first wave of the corona crisis mainly focused on minor inconveniences.

\section{PHASING: FROM FAR AWAY TO AWFULLY CLOSE}

Like the virus, the jokes and memes came in waves. First, racist jokes were mainly made about weird Chinese people who eat strange food, such as bats. An artist called Toon of Rotterdam composed a carnival song, entitled "Beter Voorkomen dan Chinezen", which literally means "Better Prevention than Chinese", a wordplay on the proverb "Prevention is better than cure". Already in early February, this song was reported by the Chinese community as discriminatory and hateful (Chinese gemeenschap 2020). A cartoon from March (Fig. 6) illustrates well how the Chinese were viewed. The caption of the cartoon reads: "Never before collected this much from the Chinese...". The drawing shows how an Asian is removed from a (Dutch) Chinese takeaway by a man in a suit that protects against radioactive radiation and is taken to a van with a sign "Corona prevention" on it. For a long time, the fact that the outbreak took place in Wuhan meant that the Chinese and Asians in general were considered to be the "instigators" of the pandemic. As Kitta (2019: 26) says: "Narratives about disease often function as a simple, shorthand way to stigmatize outsiders. Moreover, linking an outbreak to a foreigner or immigrant can immediately exacerbate their outsider status." Remember, too, that Donald Trump eventually began referring to the corona virus as the "Chinese virus" when he began to lose his grip on the pandemic: it is a strategy to designate "the Other" as a scapegoat (Bodner et al. 2021: 29-35). ${ }^{30}$

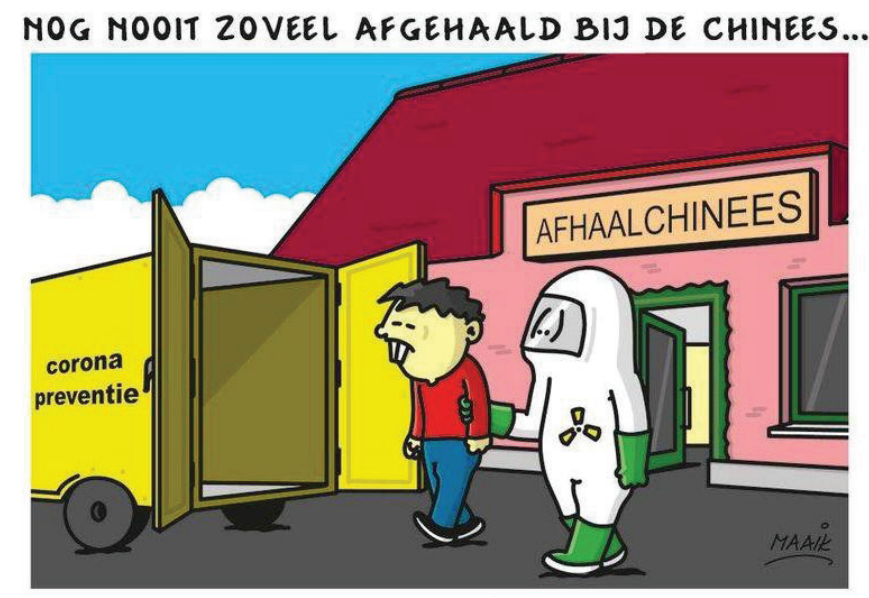

Figure 6. Cartoon: "Never before collected this much from the Chinese..." Source: http: / / www.verhalenbank.nl/items / show/128870, last accessed on 26 February 2021. 
Ik voel mij al stukken beter.

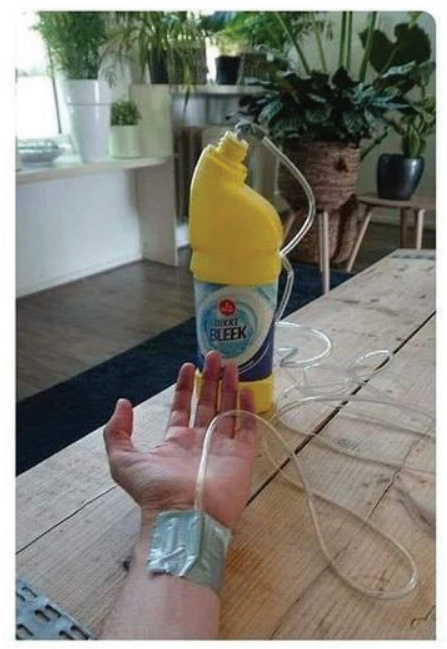

Figure 7. Hooked up to IV drip with bleach: "I already feel much better". Source: http: / / www.verhalenbank.nl/ items / show / 129343, last accessed on 26 February 2021.

In the next stage, the virus comes closer: the mockery focuses on Italy and especially on the first local outbreak in the Dutch province of Brabant; some jokes are made about Brabanders, ${ }^{31}$ but the focus quickly shifts again. The hoarding ${ }^{32}$ particularly of toilet paper, ${ }^{33}$ becomes prominent in the jokes, followed by the longest wave of quarantine jokes ${ }^{34}$ and its many inconveniences, such as lonely birthdays. In the final phase, as the tight lockdown is being slowly relaxed, jokes and memes start to get a bit grimmer and take on a polemic character. In the eyes of people, and especially entrepreneurs and the self-employed, the relaxation of the lockdown measures is not fast enough: home isolation is damaging the economy considerably. The danger of the virus is downplayed, more freedom is demanded, and protest demonstrations take place; one demonstration is allowed despite the fact that social distancing cannot be enforced (Black Lives Matter on Dam Square in Amsterdam $)^{35}$ while other demonstrations are prohibited or being dispersed by the police (The Hague, Volk Wordt Wakker and VirusWaanzin movements against the lockdown).

People started grumbling about political arbitrariness and censorship, and sentiments like these can be found in the latest memes. At that time, the oneand-a-half-meter distance measures also started to be involved in the issues that were actually unrelated to virus infections: (protests against) racism and police violence (in the US, but also in the Netherlands). The corona crisis started to shorten the fuses.

The memes usually responded to developments very quickly: Donald Trump had not yet recommended taking disinfectants, yet the first jokes about Dettol 
on the rocks ${ }^{36}$ had already been made. Several cartoons and memes showed people on an intravenous drip of disinfectant. ${ }^{37}$ In the corona era, social media was ideally suited for detecting emotions and discontent, and the multitude of memes and jokes clearly showed what people were really concerned about.

As soon as a serious relaxation of the corona measures was implemented in the Netherlands and Flanders in July, especially with regard to the lockdown, the number of corona-related jokes and memes rapidly declined, and humor largely returned to its normal routine. However, this was not the case with the modern legends, the lifespan of which was prolonged due to actions such as the Virus Madness movement (later renamed Virus Truth) and other protest groups and believers in virus hoaxes and conspiracies.

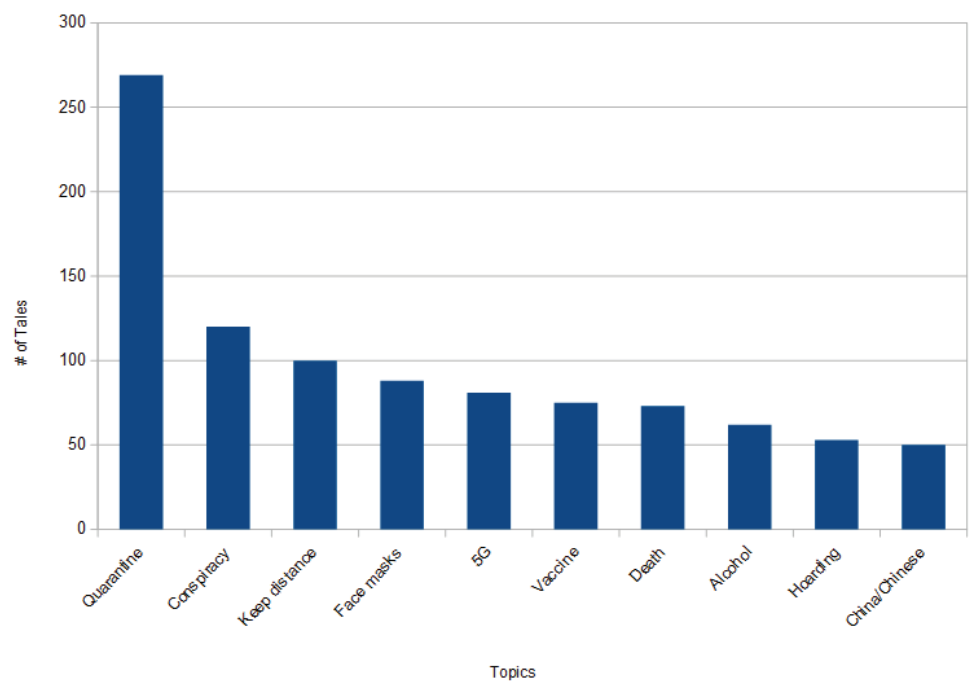

Figure 8. Top ten topics in corona folktales (jokes and legends) ( $N=769)$.

\section{FAKE NEWS AND CONSPIRACIES}

Modern or contemporary legends "provide an index to what intrigues us, concerns us, frightens us, and puzzles us about quotidian reality. They capture our thoughts and understandings of health, illness, risk, life, and death and turn those thoughts outward in ways that are not otherwise easily seen" (Goldstein 2004: XV). Incidentally, we must take into account that some of the fake news and conspiracy theories have been spread by (Russian) trolls, not out of conviction, but purely with the intention of disrupting common sense and stability in society (Assen 2020; Nepnieuws 2020). 
These modern legends that circulated on social media during the first wave of the corona crisis, represented in fake news and conspiracy theories, ${ }^{38}$ also closely followed all the developments. Plenty of (mis)information spread like an oil slick on the Internet platforms. Initially, official reporting was sparse and ambiguous. Is it going to be a terrible pandemic or is it just an outbreak of flu? People filled the gaps in the news by, for example, coming up with simple home remedies $^{39}$ to prevent or cure corona: drink water every 15 minutes, drink warm water, drink salt water, drink water with baking powder, etc. It is said that in India people even started drinking cow urine (Hindoes 2020). Gradually more reliable information started to come from the government, but for many people the line between information and misinformation remained fluid: uncertainty reigned and what seemed misinformation yesterday could be correct the next day and vice versa; for instance: the mechanism of group immunity, the need for face masks, the distinction between aircraft and coach (full of passengers or practically empty), or the risk of contamination by aerosols in confined spaces versus contamination in the open air. Very slowly the realization was growing that the greatest risk of contamination lay in indoor festivities where people sing and shout: carnivals, apres-ski, nightclubs, church services, choir singing. But the conditions in slaughterhouses also appeared to be far from optimal. For experts, the National Institute for Public Health and the Environment (RIVM), and politicians, this pandemic was also a matter of advancing insights.

Calamities spawn stories (cf. Goldstein 2004: 74). Lack of information, uncertainty about facts, and social unrest in times of crisis constitute a fertile ground for modern legends, with social media as a catalyst (Havermans 2020; Prooijen \& Vugt 2018: 784; Prooijen 2018: 23-25). Most conspiracy theories already existed roughly twenty years ago (Meder 2006: 227-240), but today everything gets magnified, and the conspiracy ideas give plenty of food to already present suspicion and frustration (Visser 2020a, 2020b). Conspiracy videos rapidly appearing on YouTube received tens of thousands to millions of likes and subscribers. As it happened with AIDS, it is constantly suspected that the coronavirus was developed by humans in a laboratory and could even be used deliberately as a bioweapon (cf. Goldstein 2004: 52-53, 80, 91-99). Over time, famous and less famous artists, influencers, and pseudo-scientists, such as Gers Pardoel, Robert Jensen, Tom Zwitser, Janet Ossebaard, David Prins, Dienie Wakker, Youri Plate, Doutzen Kroes, Robbert van den Broeke, Micha Kat, Willem Engel, Maurice de Hond and later Famke Louise spread their contemporary legends online, while the rapper Lange Frans scored a hit with his song "Lockdown (Fall Cabal)"40 with the recurring line "Welcome to this mega-weird festival", in which he professes his belief in a worldwide conspiracy and praises Janet Ossebaard, supporter of QAnon. 
People who believe in a secret agenda of the evil rulers (the elite, the cabal, the cartel, the 1 percent, the Deep State, the Bilderberg group, the Illuminati, the Reptilians) are producing memes about the danger of 5G and mandatory vaccinations, about the constitution of a police state and a global fascist dictatorship, about the "sheeple" (sheep / people) who do not want to wake up, and so on. Skeptical people post memes and jokes about the bizarre and impossible conspiracies that the "covidiots" and "tin foil hats" believe in. Once online fake news and conspiracy theories get removed by Facebook and YouTube, conspiracy theorists complain about censorship and in fact feel empowered to believe that the elite is systematically opposing them and trying to silence them. This confirms their convictions even more.

Social psychologists Elliot Aronson and Carol Tavris explain much of such behavior during the pandemic with the concept of cognitive dissonance, which is "the motivational mechanism that underlies the reluctance to admit mistakes or accept scientific findings - even when those findings can save our lives. This dynamic is playing out during the pandemic among the many people who refuse to wear masks or practice social distancing. Human beings are deeply unwilling to change their minds. And when the facts clash with their preexisting convictions, some people would sooner jeopardize their health and everyone else's than accept new information or admit to being wrong" (Aronson \& Tavris 2020). The brain then constantly searches for patterns and reacts to danger, even when there is none: "people sense danger even when there is no pattern to recognize - and so their brains create their own. This phenomenon, called illusory pattern perception ... is what drives people who believe in conspiracy theories, like climate change deniers, 9/11 truthers, and 'Pizzagate' believers" (Sloat 2020; cf. Prooijen 2018: 40).

\section{MISTRUST IN THE ELITE}

Initially, the conspiracy ideas still consisted of loose fragments (which sometimes contradicted each other, such as harmless flu versus a bioweapon), but thanks to Janet Ossebaard ${ }^{41}$ in particular, a narrative gradually crystallized in the Low Countries: corona is in fact just an ordinary flu and a smoke screen for other developments. The physical complaints that people develop are caused by the radiation from the $5 \mathrm{G}$ network, but all the conspiring doctors use COVID-19 as an excuse. People must become frightened of the virus, so that everyone will soon be ready to get vaccinated. This vaccine is being developed by Bill Gates (Fig. 10) (who, by the way, is a strong proponent of reducing the world population), and that vaccine contains nano-chips that get injected into the 
bloodstream. These chips are then in contact with the 5G network, so that everyone can be monitored and controlled anytime, anywhere. Opponents of the regime could even be silenced or killed with it.

The measure of social distancing is to make the facial recognition software work better. In this way, politicians, scientists, doctors, and journalists (that is, the MainStream Media, MSM) work together to establish a global New World Order (NWO) soon. Such meta-conspiracy theories are spread worldwide by an internet group called QAnon and many related websites, by British author David Icke and an American radio host and filmmaker Alex Jones, and the Low Countries could not escape their ideological influence either (see Wat is QAnon 2020; Icke 2000; Klomp 2020).

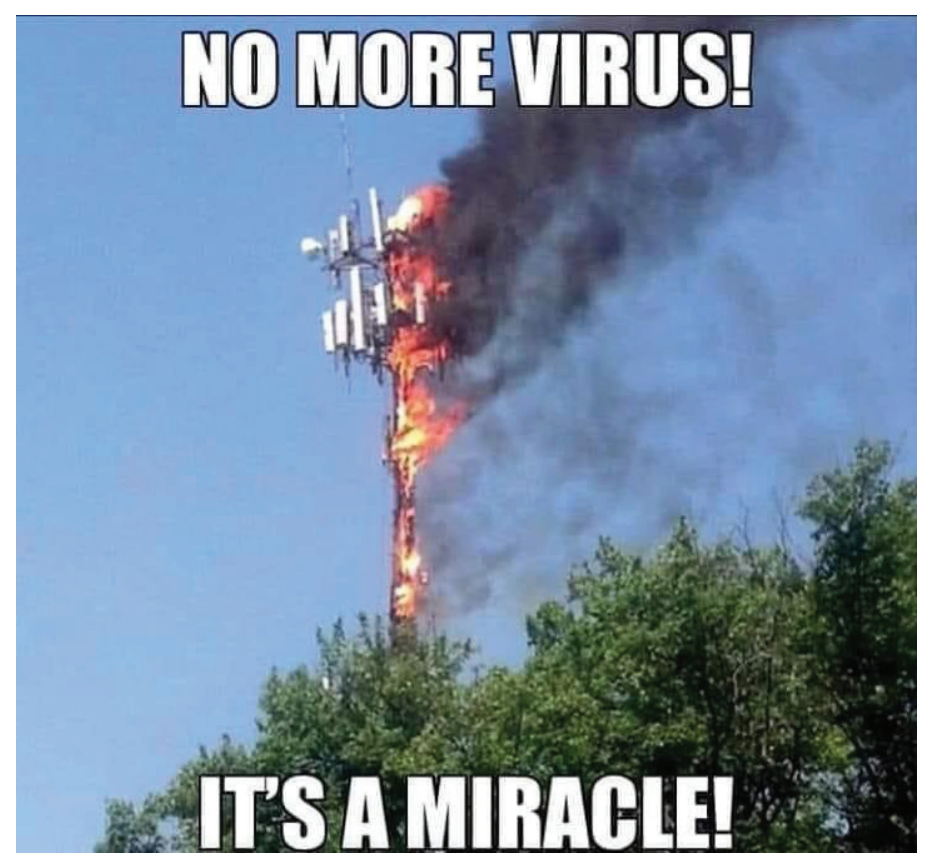

Figure 9. Burning a 5 G transmission tower that causes flu-like symptoms (or even spreads the virus). Source: http:/ / www.verhalenbank.nl/items / show/129166, last accessed on 26 February 2021. 
Figure 10. Bill Gates wants to control and kill people by putting nano chips in his vaccine. Source: http: / / www. verhalenbank.nl/items/show/129181, last accessed on 26 February 2021.

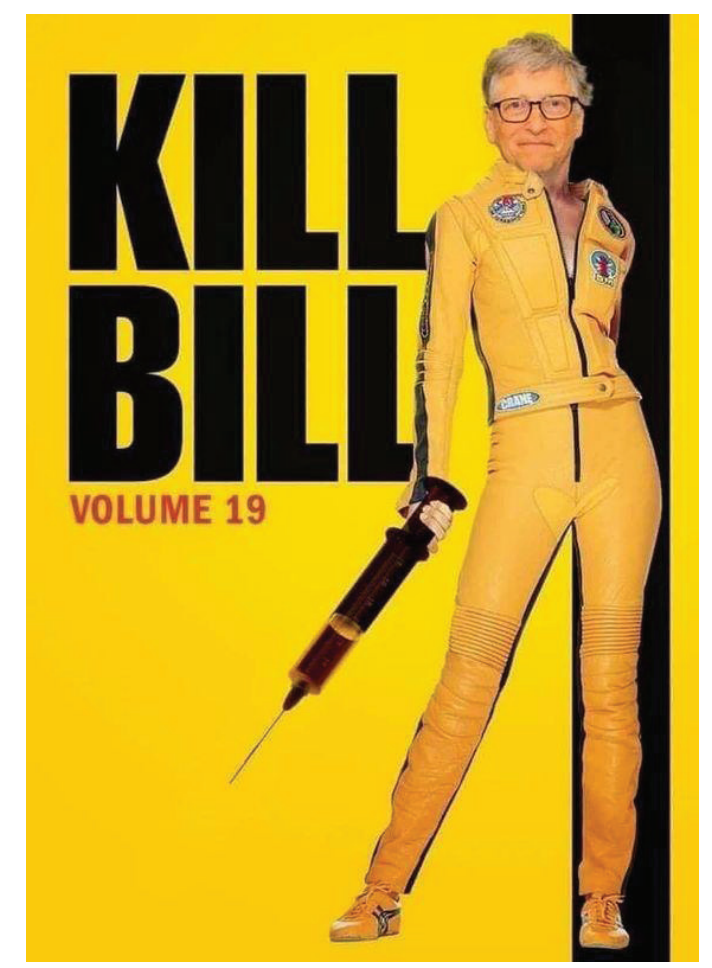

The conspiracy theories came to the surface in the course of the first wave and gradually became more prevalent. On Nu.nl, one ZussieCoolface testified:

Unfortunately, I work with several people who strongly believe in this. And believe me: it is very tiring to deal with. I hold my breath with every news item - what are they going to come up with now? In the beginning I tried to refute their positions with facts and evidence. It is always written off as untrustworthy sources and I am told that I should not believe what the 'normal' media presents to me. The stories I hear are really too crazy for words. From implanted chips to group child rapes by the elite. I am called a sheep of society because I do not go along with their madness. I keep being told that people who don't believe in it are stupid and should 'wake up'. (response in Wat is QAnon 2020)

The breeding ground for all these conspiracies seems to be deep-seated mistrust. This distrust is in fact an evolutionary ingrained psychological function, a universal survival strategy, designed to protect people from real danger. Your own group or clan can usually be trusted, but others - outsiders, strangers cannot always be trusted to the same degree. Caution is advised so that in the 
case of real malicious conspiracies one can react to danger in time (by fleeing or fighting, for example).

In the past and also in the present, however, this has also led to believing in conspiracies that did not actually exist (cf. Prooijen 2018: 24). In the Middle Ages, a marginal group like the Jews were suspected of poisoning the wells during epidemics. They were also suspected of kidnapping, murdering, and using children in satanic rituals. Other groups that have been distrusted throughout history have been women (witches), the Gypsies (child robbers), and freemasons (Satanists). Thus, the distrusted groups with malicious intentions could as well consist of a marginalized underclass as an elite with a secret, invisible alliance. Sometimes the danger from a strange group can be real, but as soon as people think they recognize hostile signs and threatening patterns that are not there, we speak of conspiracy theories. This form of illusory pattern perception can lead to all kinds of hasty conclusions and irrational (religious) beliefs (Prooijen \& Vugt 2018; Prooijen 2018: 40-48). This does not mean that we are dealing with pathological behavior: distrust is ingrained in the human species, and many people with fairly absurd suspicions can nevertheless continue to function well in society (Prooijen 2018: 15-17).

During the corona crisis, distrust is pre-eminently aimed at the elite suspected of corruption, misconduct, and a secret political agenda. In the medical field, the government, medical specialists, and the pharmaceutical industry have traditionally been under suspicion - and not always without reason (Goldstein 2004: 52, 99, 166, 171; Prooijen \& Vugt 2018: 775).

Even the American Pizzagate affair ${ }^{42}$ about powerful, suspect elites, which has been denounced several times by skeptics, reappears during the corona crisis. According to the story, a powerful elite exists, including the Clintons, the Rockefellers, and the Rothschilds, who congregate in a specific pizza restaurant, where in the sex dungeons children (supplied through secret subterranean tunnels) are abused and killed during satanic rituals (sometimes even by shapeshifting reptiles). An armed American once believed this story so much that he started shooting in the restaurant. The restaurant in question did not even have a basement. Still, this elite is held responsible for planting the virus, using $5 \mathrm{G}$, and forcing the scared population to accept vaccines with micro-chips in them - all steps from the Deep State towards a full control and a global New World Order.

During the corona crisis, a British-Dutch team from the C-TRUTH project conducted a survey into media use and belief in fake news and conspiracy theories. The survey included one open question about whether people had heard any modern legends or rumors about the coronavirus. One respondent answered: "The oak processionary caterpillar plays a role in the spread of the 
coronavirus (via Facebook)". This story can really only go back to one Internet report, "How the oak processionary caterpillar helps spread 5G" (Hoe de eikenprocessierups 2020). There were already rumors that 5G was the spreader of the coronavirus, but this message is not about that (the respondent remembered that incorrectly). The report states that where $5 \mathrm{G}$ cell towers are set on fire, the genetically engineered oak processionary caterpillar takes over the transmission with its antennae-like hairs. However, this post is intended to be satire, but it is written seriously enough to leave the readers in despair. Some of the readers admit that it made them laugh heartily, while others wonder whether this is true. Later, the first part of this message was again posted as a serious news on Twitter and then on the Facebook page of "Complotdenkers Nederland" (Conspiracy Thinkers Netherlands), a satirical page that makes fun of conspiracy theories. So satirical conspiracy news can also be taken seriously by some people. Yet, online communication can be more ambiguous and therefore create more misinterpretation than face-to-face communication.

One detail is true, by the way: due to the many rumors that the radiation from $5 \mathrm{G}$ would make people sick, help spread the virus, or could communicate with the nano-chips in the vaccine, nearly thirty cell towers have been set on fire in the Netherlands (and also in the UK; see Waarom worden 2020). Several perpetrators have taken the stories about the harmful 5G network seriously and acted on it. In folktale research, such a phenomenon is called ostension: modern legends influence people's behavior and can even encourage them to act in all kinds of ways (Goldstein 2004: 28-30, 120-121; Meder 2006: 241-316; 2014).

In the final phase of the first corona wave, memes and modern legends are often about the desire for freedom, about censorship and repression by the media and the government, and about doubts about the authority of the National Institute for Public Health and the Environment (RIVM); groups of people refuse to accept social distancing measures and ignore the command to wear face masks. There is plenty of resentment and anger (Havermans 2020). The "woke" action group Wij zijn het Volk (We are the people) already demonstrated in Eindhoven on May 24; it was a mixed company of yellow vests, supporters of the Nexit (Dutch exit from Europe), anti-vaxxers, and people who distrust the government and the media, who were all against the lockdown and the 1.5-meter distance measures. Some protesters were interviewed by the Eindhovens Dagblad (Nolles 2020).

S. S. from Eindhoven believes:

Very slowly, the government wants to control us more and more. The media don't want to hear our voice, but we want to speak up. Doctors who are opposed to the lockdown are being removed from YouTube. Based on incorrect information, we have locked up our elderly in nursing homes. 
That is not freedom. We think that behind the scenes a shadow government is pulling the strings. They make us so anxious that soon we won't even dare to step outside. That way they will soon be in control.

M. R. from Eindhoven states:

If there is a vaccine soon, I don't want to have it injected. For all other viruses, it takes ten years before there is a vaccine. And with corona it can suddenly be done within a year. I think that vaccine has a chip to keep track on us. They want to see where we are and who we associate with. Moreover, the media distort the facts. Full beaches in the Netherlands? They are images from a year ago. It is all wrong. We are being made afraid. My mother was recently in hospital, the staff was just picking their noses. It has never been busy there.

The developments described above are unique neither to the Netherlands and Flanders, nor to this pandemic. About the worldwide AIDS epidemic, Goldstein (2004: 8) writes that "rumor and legend revealed a deep-seated sense of concern, fear, distrust, and even resistance ... Legends focused on what was still unknown, unproven, unspoken, and most of all, uncomfortable". And she adds: "Because blame is ever present in epidemic and health crisis situations, it is not surprising that conspiracy beliefs arise as a counter-attack from those who feel disempowered in general"

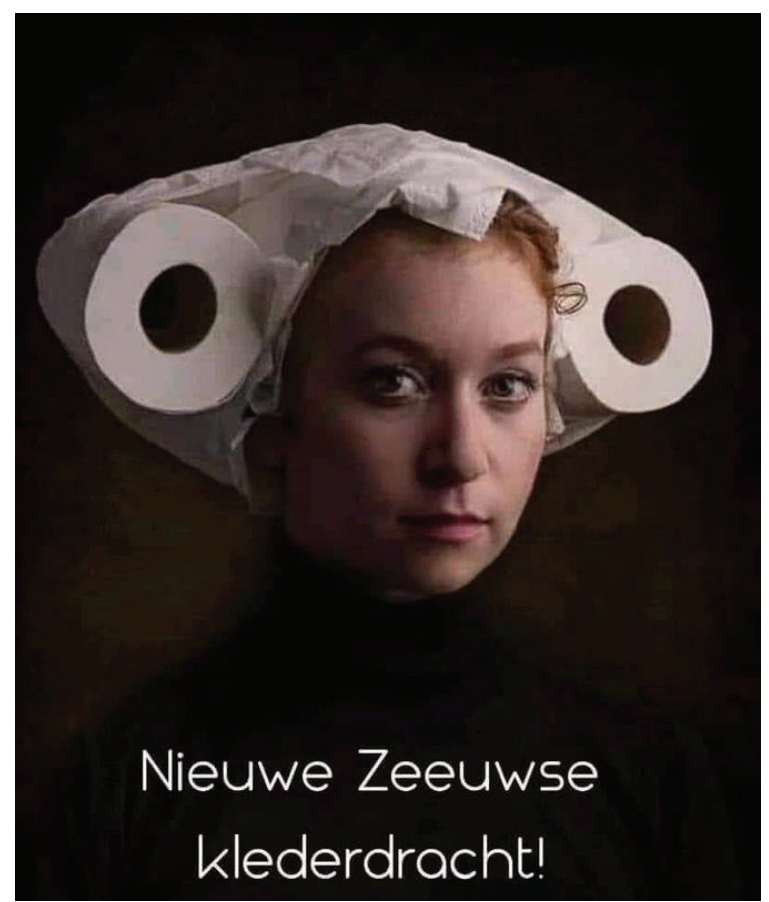
(ibid.: 53). This lack of power is an important factor in the corona crisis: the conspiracy believers who act against the elite often experience powerlessness to change what they consider an alarming situation, which in turn manifests itself in anger, protest, and aggression (see also Prooijen \& Vugt 2018: 780-781, 784).

Figure 11. Ironic comment on the hoarding of toilet paper: New folkloristic headgear from the province of Zeeland. Source: http: / / www.verhalenbank.nl/items/show/129136, last accessed on 26 February 2021. 


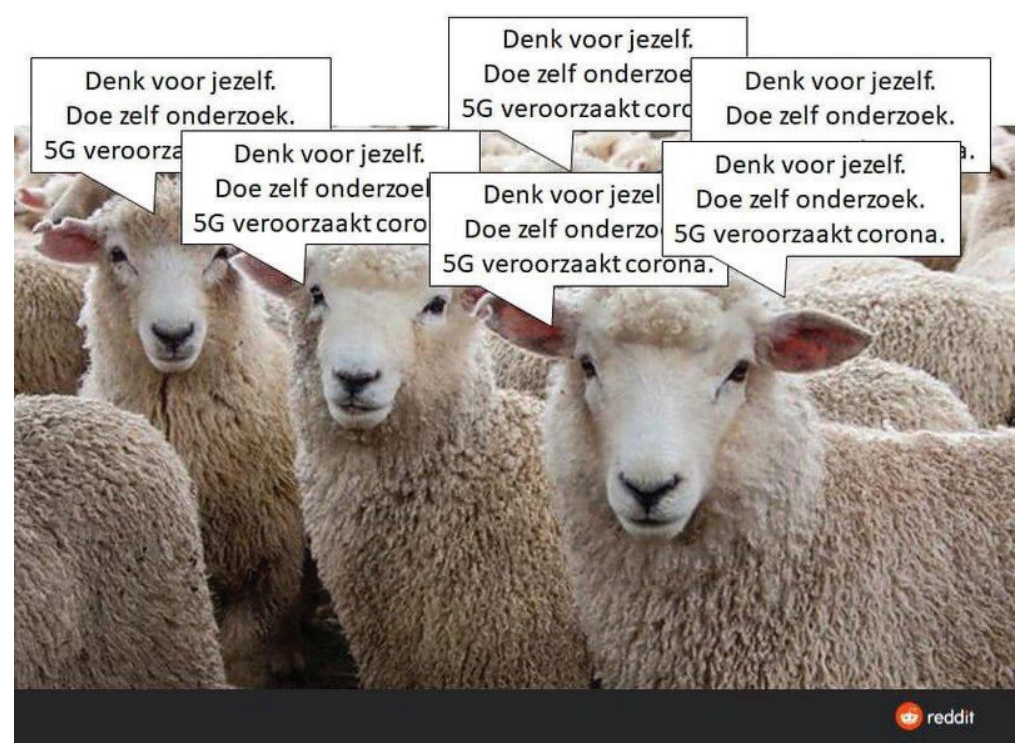

Figure 12. Conspiracy theorists as the real "sheeple": "Think for yourself. Do your own research. $5 G$ causes corona”. Source: http: / / www.verhalenbank.nl/ items / show / 129451, last accessed on 26 February 2021.

\section{TEMPERATURE OF MOODS}

Folktales can act as thermometers of feelings and emotions; jokes, memes, fake news, and conspiracy theories during the corona pandemic are good examples of this. The jokes remain good-natured for a long time during the pandemic: really painful subjects are avoided, and the harsh morbid humor remains unspoken. ${ }^{43}$ As soon as the corona measures are relaxed, the corona humor also decreases rapidly, in contrast to the modern legends that linger on much longer and more aggressively. The fierceness and toxicity are therefore mainly to be found in modern legends. ${ }^{44}$ In that respect, the corona crisis even seems to be a booster that is making previously odd and marginal conspiracy theories more and more mainstream, in which mistrust of elitist groups is being fueled: the government, scientists, journalists, etc. Conspiracy theorist and protest leader Willem Engel predicted a bloody revolt against parliamentarians in August (which did not take place, by the way), while rap artist Lange Frans and QAnon supporter Janet Ossebaard wondered on YouTube who should shoot Prime Minister Mark Rutte (Teeffelen 2020; Akkerman 2020). The polarization has taken serious forms in the Netherlands and Flanders, but just as well on a global scale. Facts hardly matter in emotional debates. Those who believe firmly in the conspiracies will 
not be easily confused. Or, as Hester Zitvast (2020) puts it: "After countless columns about vaccination, I should have known that having a discussion with people who have taken a turn towards suspicion is completely pointless." At best, facts or the ridicule of anti-legends can change the people in doubt.

Anti-legends initially look the same as legends, but eventually turn everything into absurdity, thus providing a humorous commentary on the legend (Ellis 2004). Doubters can thus see the absurdity of certain views. During the corona crisis, various anti-legends $\mathrm{s}^{45}$ appeared on Dutch and Flemish social media. Several times the following message was distributed in different variations, sometimes with a logo of the Dutch or Flemish government or the RIVM:

Important RIVM research

Tomorrow evening between 6:00 PM and 11:00 PM, a satellite with UltraLasers will measure the body temperature of the population to map the current level of infection with Covid-19.

It is very important that you stand naked on the balcony, in the garden or in front of the front door and hold your ID card up in your right hand. Thank you for your cooperation. ${ }^{46}$

The communication scoffs at the belief in science-fiction-like technologies with which the government would (can / will) constantly control the entire population. The requirement to stand outside naked turns the message ridiculous.

The lack of harsh jokes and the highly polarizing conspiracy theories are, after all, two sides of the same coin: both phenomena confirm the seriousness of the situation. You do not make harsh jokes about the deadly risks you run yourself, but you may speculate all the more seriously about the possible abuse of power and repression. It is to be hoped that the situation will return to normal as soon as a vaccine has been found, that the ideological polarization will end, and that the Netherlands and the world will not be condemned to a permanent fear of contamination. Unfortunately, by now, large parts of the world have been hit by a second and a third wave of COVID-19 variants, which keep the corona folklore going. A recent curfew in the Netherlands, partly inspired by conspiracy theories about an evil government with a hidden agenda, led to violent protests in several cities. 


\section{NOTES}

1 See http://www.verhalenbank.nl/, last accessed on 25 February 2021.

${ }^{2}$ It is hard to make an accurate estimate, but probably at least half of the memes on Dutch and Flemish social media were in British or American English. Of all the memes in the Dutch language perhaps a third were translated from English into Dutch first.

3 The author is most active on Facebook, and his co-collector used Facebook Messenger to send in memes. The research could have been focused on Twitter or Reddit just as well, but Facebook alone provided plenty of material (which needed to be entered in the Corona exhibition of the Dutch Folktale Database on a daily basis, including metadata).

4 See http://www.verhalenbank.nl/exhibits/show/corona2020/corona2020, last accessed on 4 March 2021.

5 See http://www.verhalenbank.nl/items/show/128893, last accessed on 25 February 2021.

${ }^{6}$ See http://www.verhalenbank.nl/solr-search?q=corona+AND+verveling, last accessed on 25 February 2021.

7 See http://www.verhalenbank.nl/items/show/129034, last accessed on 25 February 2021.

8 See http://www.verhalenbank.nl/items/show/129192, last accessed on 25 February 2021.

9 See http://www.verhalenbank.nl/items/show/128889, last accessed on 25 February 2021.

${ }^{10} \mathrm{See}$ http://www.verhalenbank.nl/solr-search?q=corona+AND+rijst, last accessed on 25 February 2021.

${ }^{11}$ See http://www.verhalenbank.nl/items/show/128991, last accessed on 25 February 2021.

${ }^{12}$ See http://www.verhalenbank.nl/items/show/129028, last accessed on 25 February 2021.

${ }^{13}$ See http://www.verhalenbank.nl/items/show/128963, last accessed on 25 February 2021.

${ }^{14}$ See http://www.verhalenbank.nl/items/show/129521, last accessed on 25 February 2021.

${ }^{15}$ See http://www.verhalenbank.nl/solr-search?q=corona+AND+kapper, last accessed on 25 February 2021.

${ }^{16}$ See http://www.verhalenbank.nl/items/show/129290, last accessed on 25 February 2021.

${ }^{17}$ See http://www.verhalenbank.nl/items/show/128884, last accessed on 25 February 2021.

${ }^{18}$ See http://www.verhalenbank.nl/items/show/129304, last accessed on 25 February 2021.

${ }^{19}$ See http://www.verhalenbank.nl/items/show/128881, last accessed on 25 February 2021.

${ }^{20}$ See http://www.verhalenbank.nl/items/show/128828, last accessed on 25 February 2021.

${ }^{21}$ See http://www.verhalenbank.nl/items/show/129152, last accessed on 25 February 2021.

${ }^{22}$ See http://www.verhalenbank.nl/items/show/129139, last accessed on 25 February 2021. 
${ }^{23}$ See http://www.verhalenbank.nl/solr-search?q=corona+AND+alcohol, last accessed on 25 February 2021.

${ }^{24}$ See http://www.verhalenbank.nl/items/show/128922, last accessed on 25 February 2021.

${ }^{25}$ See http://www.verhalenbank.nl/items/show/129616, last accessed on 25 February 2021.

${ }^{26}$ See http://www.verhalenbank.nl/items/show/129336, last accessed on 25 February 2021.

${ }^{27}$ See http://www.verhalenbank.nl/solr-search?q=corona+AND+cafe, last accessed on 25 February 2021.

${ }^{28}$ See http://www.verhalenbank.nl/items/show/128780, last accessed on 25 February 2021.

${ }^{29}$ See http://www.verhalenbank.nl/items/show/129030, last accessed on 25 February 2021.

${ }^{30}$ See also "the Other", "stranger danger", and the "obsession with origins" in Goldstein (2004: 45-52, 77-78).

${ }^{31}$ See http://www.verhalenbank.nl/solr-search?q=corona+AND+brabant+AND+besmet tingshaard, last accessed on 26 February 2021.

${ }^{32}$ See http://www.verhalenbank.nl/solr-search?q=corona+AND+hamsteren, last accessed on 26 February 2021.

${ }^{33}$ See http://www.verhalenbank.nl/solr-search?q=corona+AND+\%22wc-papier\%22, last accessed on 26 February 2021.

${ }^{34}$ See http://www.verhalenbank.nl/solr-search?q=corona+AND+quarantaine, last accessed on 26 February 2021.

${ }^{35}$ See http://www.verhalenbank.nl/items/show/129652, last accessed on 26 February 2021.

${ }^{36}$ See http://www.verhalenbank.nl/items/show/129328, last accessed on 26 February 2021.

${ }^{37}$ See http://www.verhalenbank.nl/solr-search?q=corona+AND+ontsmettingsmiddel+A ND+infuus, last accessed on 26 February 2021.

${ }^{38}$ See http://www.verhalenbank.nl/solr-search?q=corona+AND+complot, last accessed on 26 February 2021.

${ }^{39}$ See http://www.verhalenbank.nl/solr-search?q=corona+AND+wondermiddel, last accessed on 26 February 2021.

${ }^{40}$ See http://www.verhalenbank.nl/items/show/129190, last accessed on 26 February 2021.

${ }^{41}$ See http://www.verhalenbank.nl/solr-search?q=corona+AND+ossebaard, last accessed on 26 February 2021.

${ }^{42}$ Seehttp://www.verhalenbank.nl/solr-search?q=pizzagate, lastaccessed on 26 February 2021.

${ }^{43}$ See http://www.verhalenbank.nl/solr-search?q=corona\&facet=58_s\%3A\%22mop\%22 $\&$ free=, last accessed on 26 February 2021.

${ }^{44}$ See http://www.verhalenbank.nl/solr-search?q=corona\&facet=58_s\%3A\%22broodjea apverhaal\%22\&free=, last accessed on 26 February 2021. 
${ }^{45}$ See http://www.verhalenbank.nl/solr-search?q=corona+AND+\%22anti-sage\%22, last accessed on 26 February 2021.

${ }^{46}$ See http://www.verhalenbank.nl/items/show/128983, last accessed on 26 February 2021.

\section{REFERENCES}

Akkerman, Stevo 2020. Dat duistere krachten het op ons hebben voorzien, wordt nu ook in ons parlement gepredikt. [That Dark Forces Are Threatening Us Is Now Also Being Preached in Our Parliament.] Trouw, 7 August. Available at https:// www.trouw.nl/opinie/dat-duistere-krachten-het-op-ons-hebben-voorzien-wordtnu-ook-in-ons-parlement-gepredikt b1e8a42c/, last accessed on 2 March 2021.

Aronson, Elliot \& Tavris, Carol 2020. The Role of Cognitive Dissonance in the Pandemic. The Atlantic, 12 July. Available at https://www.theatlantic.com/ideas/ archive/2020/07/role-cognitive-dissonance-pandemic/614074/, last accessed on 2 March 2021.

Assen, Mark van 2020. Russisch nepnieuws: Corona is een grap of een biologisch wapen. [Russian Fake News: Corona Is a Joke or a Biological Weapon.] AD, 24 March. Available at https://www.ad.nl/buitenland/russisch-nepnieuws-corona-is-eengrap-of-een-biologisch-wapen ab07fd1e/, last accessed on 2 March 2021.

Bodner, John \& Welch, Wendy \& Brodie, Ian \& Muldoon, Anna \& Leech, Donald \& Marshall, Ashley 2021. Covid-19 Conspiracy Theories. QAnon, 5G, the New World Order and Other Viral Ideas. Jefferson: McFarland \& Company.

Chinese gemeenschap $2020=$ Chinese gemeenschap doet aangifte wegens "discriminerend en haatzaaiend" lied. [Chinese Community Reports "Discriminatory and Hateful" Song.] NOS Nieuws, 10 February. Available at https://nos.nl/artikel/2322431chinese-gemeenschap-doet-aangifte-wegens-discriminerend-en-haatzaaiend-lied. html, last accessed on 2 March 2021.

Ellis, Bill 2004. Legend/Antilegend: Humor as an Integral Part of the Contemporary Legend Process. In: Gary Alan Fine \& Véronique Campion-Vincent \& Chip Heath (eds.) Rumor Mills: The Social Impact of Rumor and Legend. New Brunswick: Routledge, pp. 123-140.

Goldstein, Diane E. 2004. Once Upon a Virus: AIDS Legends and Vernacular Risk Perception. Logan: Utah State University Press. Available at https:// digitalcommons.usu.edu/usupress_pubs/32/, last accessed on 25 February 2021.

Havermans, Jelle 2020. De complotdenker radicaliseert in crisistijd. [The Conspiracy Believer Radicalizes in Times of Crisis.] JOOP, 13 May. Available at https://joop. bnnvara.nl/opinies/de-complotdenker-radicaliseert-in-crisistijd, last accessed on 2 March 2021.

Hindoes $2020=$ Hindoes drinken koeienurine in strijd tegen coronavirus. [Hindus Drink Cow Urine to Fight Coronavirus.] De Telegraaf, 14 March. Available at https:// www.telegraaf.nl/nieuws/964802889/hindoes-drinken-koeienurine-in-strijdtegen-coronavirus, last accessed on 2 March 2021. 
Hoe de eikenprocessierups $2020=$ Hoe de eikenprocessierups $5 \mathrm{G}$ helpt verspreiden . [How the Oak Processionary Caterpillar Helps Spread 5G.] The Untold Truth, 3 May. Available at https://theuntoldtruth5g.wordpress.com/2020/05/03/hoe-deeikenprocessierups-5g-helpt-verspreiden/, last accessed on 26 February 2021.

Icke, David 2000. The Biggest Secret: The Book That Will Change the World. Wildwood: Blackwell.

Kitta, Andrea 2019. The Kiss of Death: Contagion, Contamination, and Folklore. Louisville: Utah State University Press.

Klomp, Chris 2020. Hoe complotdenkers ons in gevaar brengen. [How Conspiracy Theorists Put Us in Danger.] 25 March. Available at https://chrisklomp.nl/hoecomplotdenkers-ons-in-gevaar-brengen/, last accessed on 2 March 2021.

Kuipers, Giselinde 2002. Media Culture and Internet Disaster Jokes: Bin Laden and the Attack on the World Trade Center. European Journal of Cultural Studies, Vol. 5, No. 4, pp. 450-470. https://doi.org/10.1177\%2F1364942002005004296.

Kuipers, Giselinde 2005. "Where Was King Kong When We Needed Him?" Public Discourse, Digital Disaster Jokes, and the Function of Laughter after 9/11. The Journal of American Culture, Vol. 28, No. 1, pp. 70-84. Available at https://www. academia.edu/1166956/, last accessed on 2 March 2021.

Kuipers, Giselinde 2020. Onderzoeker naar Coronagrappen: Harde humor over corona heb ik nog amper gezien. [Researcher into Corona Jokes: I've Hardly Seen Harsh Humor About Corona.] De Volkskrant, 13 April. Available at https://www. volkskrant.nl/wetenschap/onderzoeker-naar-coronagrappen-harde-humor-overcorona-heb-ik-nog-amper-gezien bba358e8/, last accessed on 2 March 2021.

Meder, Theo 2006. In Graancirkelkringen: Een Etnologisch Onderzoek naar Verhalen uit de Grenswetenschap. [In Crop Circle Circles: An Ethnological Research into Stories from Frontier Science.] Amsterdam: Amsterdam University Press.

Meder, Theo 2014. Ostension. In: Enzyklopädie des Märchens, Vol. 14, No. 4. Berlin \& Boston: Walter de Gruyter, col. 1760-1761. Available at https://pure.knaw.nl/ ws/portalfiles/portal/792966/Ostension.pdf, last accessed on 2 March 2021.

Nepnieuws 2020 = Zeker vijftig accounts verspreiden nepnieuws over corona in Nederland. [At Least Fifty Accounts Spread Fake News About Corona in the Netherlands.] NOS Nieuws, 21 August. Available at https://nos.nl/artikel/2344875-zeker-vijftigaccounts-verspreidden-nepnieuws-over-corona-in-nederland.html, last accessed on 2 March 2021.

Nolles, Jurriaan 2020. Demonstratie tegen de lockdown: "Wij zijn het volk, wij willen terug naar het normaal". [Demonstration against the Lockdown: "We Are the People, We Want to Go Back to Normal".] Eindhovens Dagblad, 24 May. Available at https://www.ed.nl/eindhoven/demonstratie-tegen-de-lockdown-wij-zijn-hetvolk-wij-willen-terug-naar-het-normaal ac37564d/, last accessed on 2 March 2021.

Prooijen, Jan-Willem van 2018. The Psychology of Conspiracy Theories. Oxon: Routledge. Prooijen, Jan-Willem van \& Vugt, Mark van 2018. Conspiracy Theories: Evolved Functions and Psychological Mechanisms. Perspectives on Psychological Science, Vol. 13, No. 6, pp. 770-788. https://doi.org/10.1177\%2F1745691618774270. 
Sloat, Sarah 2020. Conspiracy Theorists Have a Fundamental Cognitive Problem, Say Scientists. Getpocket.com. Available at https://getpocket.com/explore/item/ conspiracy-theorists-have-a-fundamental-cognitive-problem-say-scientists, last accessed on 2 March 2021.

Teeffelen, Kristel van 2020. Praten over wie Mark Rutte gaat doodschieten op YouTube: is Lange Frans schuldig aan opruiing? [Talking about Who Is Going to Shoot Mark Rutte on YouTube: Is Lange Frans Guilty of Sedition?] Trouw, 7 August. Available at https://www.trouw.nl/binnenland/praten-over-wie-mark-rutte-gaatdoodschieten-op-youtube-is-lange-frans-schuldig-aan-opruiing be0c0828/, last accessed on 2 March 2021.

Visser, Marco 2020a. Eén op de tien Nederlanders gelooft dat er rond corona vieze spelletjes worden gespeeld. [One in Ten Dutch Believe That Dirty Games Are Being Played Around Corona.] Trouw, 15 August. Available at https://www.trouw. $\mathrm{nl} /$ binnenland/een-op-de-tien-nederlanders-gelooft-dat-er-rond-corona-viezespelletjes-worden-gespeeld bd98ce41/, last accessed on 2 March 2021.

Visser, Marco 2020b. Een pandemie is voedsel voor complottheorieën: die bloeien als nooit tevoren. [A Pandemic Is Food for Conspiracy Theories: They Are Flourishing Like Never Before.] Trouw, 23 August. Available at https://www.trouw.nl/ binnenland/een-pandemie-is-voedsel-voor-complottheorieen-die-bloeien-als-nooittevoren b7224923/, last accessed on 2 March 2021.

Waarom worden 2020 = Waarom worden door heel Nederland zendmasten in brand gestoken? [Why Are Transmission Towers Set on Fire Throughout the Netherlands?] NOS Nieuws, 11 April. Available at https://nos.nl/artikel/2330187waarom-worden-door-heel-nederland-zendmasten-in-brand-gestoken.html, last accessed on 2 March 2021.

Wat is QAnon 2020 = Wat is QAnon, de complottheorie die "oorlog tussen werkelijkheden" uitlokt? [What Is QAnon, the Conspiracy Theory That Provokes "War Between Realities"?] Nu.nl, 22 July. Available at https://www.nu.nl/techachtergrond/6066028/wat-is-qanon-de-complottheorie-die-oorlog-tussenwerkelijkheden-uitlokt.html, last accessed on 2 March 2021.

Zitvast, Hester 2020. Nee Doutzen, we moeten dus helemaal niet allemaal zelfstudie doen. [No, Doutzen, We Should Not All Do Self-Study at All.] De Telegraaf, 24 July. Available at https://www.telegraaf.nl/vrouw/1323289709/nee-doutzen-we-moetendus-helemaal-niet-allemaal-zelfstudie-doen, last accessed on 2 March 2021.

Theo Meder is Senior Research Fellow of Dutch Folktales at the Meertens Instituut in Amsterdam and Professor of Dutch Folktales and Narrative Culture at the University of Groningen, Netherlands. He is coordinator of the Dutch Folktale Database (www.verhalenbank.nl) and project leader of the Intelligent Search Engine for Belief Legends (ISEBEL); www.isebel.eu). Currently he is also President of the International Society for Contemporary Research (ISCLR). He has published books about fairytales, legends and jokes, and written articles in 
international journals, such as Fabula, Folklore, Humor, Contemporary Legend, Methis, Digital Scholarship in the Humanities, Western Folklore, Journal of American Folklore, and in the Enzyklopädie des Märchens. He is editor of a Dutch online journal called Vertelcultuur.

Theo.Meder@Meertens.knaw.nl

T.Meder@RUG.nl 